\title{
Pengaruh Gaya Kepemimpinan, Komitmen Organisasi dan Motivasi Kerja Terhadap Kinerja Perusahaan
}

\author{
Ni Kadek Putri Sartika ${ }^{1}$ \\ Fakultas Ekonomi dan Bisnis \\ Universitas Udayana, Indonesia. \\ Email: artikaputri2894@gmail.com
}

\author{
I Nym Wijana Asmara Putra2 \\ Fakultas Ekonomi dan Bisnis \\ Universitas Udayana, Indonesia.
}

\begin{abstract}
ABSTRAK
Penelitian ini dilakukan di PT. Sejahtera Indobali Trada seluruh Cabang yang ada di Bali. Pengumpulan data dilakukan dengan kuesioner dengan teknik sampling jenuh. Jumlah karyawan yang menjadi responden adalah sebanyak 46 orang. Metode Analisis Data yang digunakan dalam penelitian ini adalah dengan menggunakan analisis regresi linier berganda. Berdasarkan hasil analisis ditemukan bahwa Gaya Kepemimpinan berpengaruh positif dan signifikan terhadap kinerja perusahaan. Hal ini menunjukkan bahwa semakin sesuai gaya kepemimpinan seorang pemimpin akan semakin meningkatkan kinerja perusahaan tersebut. Komitmen organisasi berpengaruh positif dan signifikan terhadap kinerja perusahaan. Hal ini menunjukkan bahwa semakin tinggi tingkat komitmen organisasi maka akan semakin tinggi kinerja perusahaan tersebut. Motivasi kerja berpengaruh positif dan signifikan terhadap kinerja perusahaan. Hal ini menunjukkan bahwa semakin tinggi tingkat motivasi kerja maka akan semakin tinggi kinerja perusahaan tersebut.
\end{abstract}

Kata Kunci : Gaya Kepemimpinan; Komitmen Organisasi; Motivasi; Kinerja.

\section{The Effect of Leadership Style, Organizational Commitment and Work Motivation on Company Performance}

\section{ABSTRACT}

This research was conducted at PT. Prosperous Indobali Trada all branches in Bali. Data collection is done by questionnaire with saturated sampling technique. The number of employees who become respondents is as many as 46 people. Data Analysis Method used in this research is to use multiple linear regression analysis. Based on the results of the analysis found Leadership Style has a positive and significant effect on company performance. This shows that the greater the leadership style the company will increase. Positive and significant organizational commitment to the company's performance. This shows the higher level of organizational commitment, the higher the company will be. Positive and significant work motivation on company performance. This shows the higher level of work motivation, the higher the increase in the company.

\section{Keywords: Leadership Style; Organizational Commitment;} Motivation; Performance.

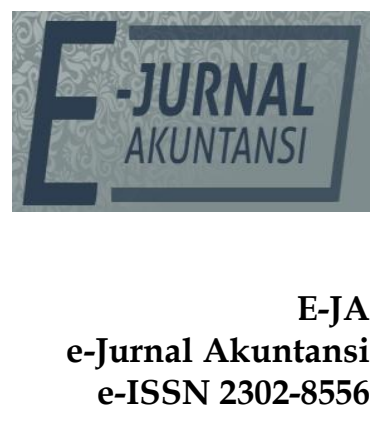

Vol. 29 No. 2

Denpasar, November

2019

Hal. 791-803

Artikel masuk: 17 September 2019

Tanggal diterima: 05 November 2019 


\section{PENDAHULUAN}

Di era globalisasi saat ini alat transportasi merupakan sesuatu yang sangat dibutuhkan oleh semua orang, dengan adanya alat transportasi maka jarak tempuh ataupun tingkat mobilitas seseorang akan semakin meningkat. Perkembangan zaman seiring dengan perkembangan jenis-jenis alat transportasi yang juga semakin bervariasi, salah satu alat transportasi yang sangat disukai oleh masyarakat adalah mobil. Kebutuhan alat transportasi ini membuat pasar otomotif nasional dewasa ini senantiasa mengalami kemajuan yang cukup pesat. Hal ini terjadi karena munculnya produk-produk baru baik mobil impor (build-up) maupun mobil-mobil produksi dalam negeri. Peningkatan inovasi dan suplay tersebut membuat dealer-dealer dari berbagai merek kendaraan kini semakin gencar mempromosikan produk baru.

Bali dengan perkembangan pariwisatanya yang semain pesat kini juga memiliki mobilitas yang sangat tinggi. Hal tersebut sejalan dengan semakin meningkatnya volume kendaraan di Bali. Berdasarkan data Badan Pusat Statistik (BPS) Provinsi Bali, volume kendaraan di Bali senantiasa mengalami peningkatan setiap tahunnya. Adapun data jumlah kendaraan di masingmasing Kabupaten/Kota di Bali dalam kurun waktu taun 2010 sampai dengan 2017 adalah terjadi peningkatan jumlah kendaraan di seluruh Kabupaten/Kota di Provinsi Bali. Pada tahun 2017 tercatat jumlah kendaraan di Bali adalah sebanyak 3.907.094 unit kendaraan. Jumlah kendaraan terbanyak adalah di Kota Denpasar yakni sebanyak 1.292.618 unit. Sementara Kabupaten Badung merupakan kabupaten dengan jumlah kendaraan terbanyak kedua yakni sebanyak 796.657 unit, dan Kabupaten Gianyar sebagai Kabupaten dengan jumlah kendaraan terbanyak ketiga yakni sebanyak 408.582 unit.

Jika ditinjau dari sisi merek, berbagai merek otomotif khususnya kendaraan roda empat (mobil) telah berkembang pesat di Bali. Berdasarkan data dari GAIKINDO (Gabungan Industri Kendaraan Bermotor Indonesia), penjualan mobil di Indonesia pada tahun 2018 terdapat 30 merek mobil yang bersaing di Indonesia dan merek Toyota merupakan merek yang menduduki posisi penjualan terbanyak, sementara merek Daihatsu, Honda dan Suzuki menduduki peringkat lima besar merek mobil paling laris di Indonesia.

Di Bali salah satu merek mobil yang juga paling banyak diminati adalah Suzuki. Dikutip dari detik.com tanggal 17 Pebruari 2019, penjuaan Suzuki di Bali menduduki peringkat kedua, dengan penjualan mencapai angka 2.700 atau menguasai $24 \%$ pangsa pasar otomotif di Bali (www.oto.detik.com) diakses tanggal 17 Pebruari 2019). PT Sejahtera Indobali Trada merupakan revolusi dari PT United Indobali yang berpusat di Jalan Teuku Umar Barat Desa Padangsambian Kelod Denpasar. PT Sejahtera Indobali Trada merupakan perusahaan main dealer Suzuki mobil di Bali.

PT. Sejahtera Indobali Trada memiliki 10 cabang di Kabupaten/Kota di Bali. Keberadaan PT. Sejahtera Indobali Trada diharapkan mampu mengakomodasi konsumen mobil Suzuki yang semakin meningkat di Bali. Berdasarkan data penjualan PT. Sejahtera Indobali Trada tahun 2018, cabang Gianyar menduduki angka penjualan tertinggi dibandingkan dua cabang lainnya seperti cabang Bangli dan Karangasem. Adapun data penjualan ketiga cabang 
yang termasuk kedalam kategori Region Bali Timur (Gianyar, Bangli, Karangasem) tahun 2018 adalah seperti pada Tabel 1.

Tabel 1. Data Penjualan PT. Sejahtera Indobali Trada Bali Tahun 2018

\begin{tabular}{|c|c|c|c|c|c|c|c|}
\hline \multirow{3}{*}{ No } & \multirow{3}{*}{ Bulan } & \multicolumn{6}{|c|}{ Cabang } \\
\hline & & \multicolumn{2}{|c|}{ Gianyar (SO105) } & \multicolumn{2}{|c|}{ Karangasem (SO108) } & \multicolumn{2}{|c|}{ Bangli (SO110) } \\
\hline & & Unit & Penjuaan & Unit & Penju & $\begin{array}{c}\text { Uni } \\
\mathrm{t}\end{array}$ & Penjuaan \\
\hline 1 & Januari & 37 & $5,110,255,000$ & 11 & $2,785,350,000$ & 24 & $1,359,050,000$ \\
\hline 2 & Pebru & 15 & $1,329,800,000$ & 13 & $1,282,500,000$ & 11 & $2,899,500,000$ \\
\hline 3 & Maret & 33 & $4,787,310,000$ & 13 & $1,279,500,000$ & 9 & $1,860,500,000$ \\
\hline 4 & April & 35 & $4,869,500,000$ & 10 & $1,582,500,000$ & 13 & $1,414,000,000$ \\
\hline 5 & Mei & 27 & $2,221,500,000$ & 11 & $1,616,730,000$ & 11 & $1,368,270,000$ \\
\hline 6 & Juni & 30 & $4,185,000,000$ & 4 & $2,811,000$ & 20 & $456,000,000$ \\
\hline 7 & Juli & 38 & $5,209,500,000$ & 6 & 1,02 & 8 & $753,500,000$ \\
\hline 8 & Agus & 43 & $6,592,000,000$ & 15 & 1,07 & 9 & $1,799,000,000$ \\
\hline 9 & Septembe & 37 & $5,178,000,000$ & 13 & 1,28 & 11 & $2,002,000,000$ \\
\hline 10 & Oktober & 24 & $3,231,000,000$ & 21 & 1,507,000, & 11 & $2,899,500,000$ \\
\hline 11 & Nope & 43 & 5,976 & 15 & 1,51 & 12 & $2,087,000,000$ \\
\hline 12 & Desember & 40 & $5,334,200,000$ & 12 & $1,771,000,000$ & 12 & $1,652,700,000$ \\
\hline & TOTAL & 359 & $\begin{array}{c}54,024,565,00 \\
0\end{array}$ & 131 & $18,247,080,000$ & 140 & $\begin{array}{c}17,651,520,00 \\
0\end{array}$ \\
\hline
\end{tabular}

Sumber: PT. Sejahtera Indobali Trada, 2018

Tabel 1 menunjukkan bahwa penjualan produk pada PT. Sejahtera Indobali Trada rata-rata menunjukkan peningkatan di setiap cabangnya. Pencapaian PT. Sejahtera Indobali Trada sebagai cabang dengan penjualan tertinggi di Bali tidak terlepas dari kinerja karyawan (Sumber Daya Manusia) yang mendukung jalannya perusahaan.

Sumber daya manusia merupakan bagian penting dalam mencapai tujuan organisasi. Salah satu faktor yang mempengaruhi keberhasilan usaha ialah sumber daya manusia karena sumberdaya manusia adalah pelaku dari keseluruhan tingkat perencanaan sampai evaluasi pada suatu perusahaan (Suwati, 2013). Untuk mencapai tujuan perusahaan tidak cukup hanya dengan peralatan yang canggih tapi juga diperlukan sumber daya manusia yang bisa melakukan pekerjaan tersebut. Setiap perusahaan dan organisasi akan meningkatkan kinerja karyawannya untuk bisa mencapai tujuan perusahaan itu sendiri sehingga kinerja perusahaan juga semakin meningkat (Hendrianto, 2015).

Dalam mengelola unsur manusia ini, sebuah lembaga tidak akan lepas dari fungsi kepemimpinan. Yang sering menjadi hambatan adalah bagaimana pemimpin mengarahkan karyawan menuju arah yang lebih baik, dengan memperhatikan faktor motivasi mereka. Aktivitas pegawai dalam mencapai tujuan organisasi tidak terlepas dari peran pimpinan dalam mengelola bawahannya. Tujuan organisasi dapat tercapai dengan baik jika pimpinan dapat mengelola aktivitas manajemen bawahan serta melaksanakan fungsi manajemen yaitu: perencanaan, pengarahan, pengorganisasian dan kontrol.

Elemen yang bernilai penting dalam sistem manajemen perusahaan selain motivasi kerja kepada para karyawan adalah kepemimpinan (leadership). Hasil dari beberapa penelitian me- nunjukkan bahwa kepemimpinan sangat diperlukan untuk meningkatkan daya saing perusahaan secara berkelanjutan. Kepemimpinan adalah 
suatu proses dimana seseorang dapat menjadi pemimpin (leader) melalui aktivitas yang terus menerus sehingga dapat mempengaruhi yang dipimpinnya (followers) dalam rangka untuk mencapai tujuan organisasi atau perusahaan.

Seorang pemimpin secara umum akan menggunakan gaya kepemimpinan sesuai dengan kemampuan dan kepribadiannya (Basuki, 2016). Gaya kepemimpinan merupakan sebuah norma prilaku yang digunakan oleh seseorang pada saat orang tersebut mencoba mempengaruhi perilaku orang lain (Handoko, 2003). Gaya kepemimpinan atasan dapat berpengaruh pada kinerja pegawai dalam suatu organisasi. Di era globalisasi ini, karyawan bukan hanya dipandang sebagi seorang pekerja yang yang mencari dafkah pada sebuah organisasi, namun jauh dari pada itu saat ini karyawan telah dipandang sebagai sebuah asset bagi perusahaan. Untuk itu pola kepemimpinan yang dulunya bersifat tradisional, kini telah bergeser pada gaya kepemimpinan yang bersifat transformasional. Kepemimpinan transformasional adalah kepemimpinan yang mentransformasi ide dan gagasannya kepada bawahan sehingga bawahan terinspirasi untuk mewujudkannya. Kepemimpinan model ini lebih mengedepankan pada ketaatan kepada pimpinan secara totalitas, sehingga apa yang diinginkan atau diperintahkan pimpinan, dilaksanakan secara absolut tanpa adanya penolakan ataupun argumentasi (Yukl, 2013:67).

Selain faktor gaya kepemimpinan, komitmen organisasi merupakan faktor penting dalam peningkatan kinerja perusahaan. Komitmen orgainsasi merupakan usaha untuk mengidentifikasikan diri dan melibatkan diri dalam organisasi dan berharap tetap menjadi anggota organisasi . Komitmen organisasi diperlukan sebagai salah satu hal yang mempengaruhi kinerja perusahaan. Komitmen organisasi pada pegawai yang tinggi biasanya akan meningkatkan kinerja yang tinggi dan sekaligus dapat menurunkan tingkat absensi dan sebaliknya jika seorang pegawai memiliki tingkat komitnen rendah maka kinerjanya juga rendah. Selain gaya kepemimpinan dan komitmen organisasi, motivasi kerja karyawan merupakan salah satu faktor yang mampu meningkatkan kinerja perusahaan. Motivasi kerja merupakan salah satu faktor yang mempengaruhi kinerja karyawan. Motivasi merupakan proses untuk mencoba mempengaruhi seseorang untuk melakukan sesuatu yang diinginkan. Motivasi menunjukkan bagaimana cara memberikan dorongan terhadap gairah kerja bawahan, supaya mau bekerja keras dengan memberikan semua ketrampilan dan kemauannya untuk mewujudkan tujuan perusahaan. Manajer perlu mengarahkan motivasi dengan menciptakan kondisi (iklim) organisasi melalui pembentukan budaya kerja atau budaya organisasi sehingga para karyawan merasa terpacu untuk bekerja lebih keras agar kinerja yang dicapai juga tinggi. Pemberian motivasi harus diarahkan dengan baik menurut prioritas dan dapat diterima dengan baik oleh karyawan, karena motivasi tidak dapat diberikan untuk setiap karyawan dengan bentuk yang berbeda-beda.

Beberapa penelitian sebelumnya yang menguji pengaruh gaya kepemimpinan, komitmen organisasi dan motivasi kerja terhadap kinerja organisasi telah menemukan hasil yang bervariasi atau tidak konsisiten (inkonsisten). Menurut Risqi dan Suparto (2015) gaya kepemimpinan meningkatkan kinerja organisasi. Bertolak belakang dengan hasil penelitian 
tersebut, Susantoso (2013) serta Parlinda dan Wahyuddin (2004) menemukan bahwa gaya kepemimpinan menurunkan kinerja organisasi.

Gaya kepemimpinan sangat erat kaitannya dengan pencapaian target suatu organisasi. Gaya kepemimpinan didefiniskan sebagai suatu pola menyeluruh sikap, sifat, dan keterampilan dalam mengarahkan organisasi menuju ke arah mana yang diinginkan oleh pimpinan organisasi. Ketika seorang bawahan diarahkan dengan tepat sesuai dengan keinginan pimpinan yang didasrkan pada asas kepentingan bersama, maka akan meningkatkan kinerja organisasi secara keseluruhan. Jika kepemimpinan tersebut terjadi pada suatu organisasi formal tertentu, di mana para manajer perlu mengembangkan karyawan, membangun iklim motivasi, menjalankan fungsifungsi manajerial dalam rangka menghasilkan kinerja yang tinggi dan meningkatkan kinerja, maka manajer perlu menyesuaikan gaya kepemimpinannya. Gaya kepemimpinan berkenaan dengan cara-cara yang digunakan oleh manajer untuk mempengaruhi bawahannya. Gaya kepemimpinan merupakan norma perilaku yang digunakan manajer pada saat ia mempengaruhi perilaku bawahannya. Pemimpin adalah pemain utama yang menentukan berhasil atau tidaknya suatu organisasi. Pemimpin dapat memberikan pengaruh dalam menanamkan disiplin bekerja para anggota organisasi untuk meningkatkan kinerjanya. Gaya kepemimpinan dapat mempengaruhi kreatifitas kinerja karyawan dalam melaksanakan tugasnya sebagai anggota organisasi.

Pengaruh positif tersebut menunjukkan adanya pengaruh yang searah antara gaya kepemimpinan dengan kinerja perusahaan, atau dengan kata lain dengan gaya kepemimpinan baik maka kinerja perusahaan tinggi. Hal ini juga didukung oleh hasil penelitian Kharis (2015) yang memeproleh hasil bahwa secara langsung gaya kepemimpinan berpengaruh secara positif signifikan terhadap kinerja perusahaan. Sedangkan pengaruh yang signifikan ini menunjukkan bahwa gaya kepemimpinan berpengaruh terhadap kinerja perusahaan. Kepemimpinan berpengaruh positif kuat terhadap kinerja, juga berpengaruh signifikan terhadap learning organisasi. Temuan ini memberikan indikasi bahwa gaya kepemimpinan seorang pemimpin sangat berpengaruh terhadap kinerja bawahannya, di samping itu untuk mendapatkan kinerja yang baik diperlukan juga adanya pemberian pembelajaran terhadap bawahannya. Berdasarkan hal tersebut, maka hipotesis pertama yang diajukan dalam penelitian ini adalah sebagai berikut:

$\mathrm{H}_{1}$ : Gaya Kepemimpinan berpengaruh positif pada kinerja perusahaan.

Hasil penelitian Sapitri (2016) dan Fauzan (2015) memperoleh hasil penelitian yang meunjukkan bahwa komitmen organisasi berpengaruh signifikan positif terhadap kinerja karyawan. Komitmen organisasi menunjukan suatu daya dari seseorang dalam mengidentifikasikan terlibatnya dalam suatu bagian organisasi. Komitmen organisasional dibangun atas dasar kepercayaan pekerja atas nilai-nilai organisasi, kerelaan pekerja membantu mewujudkan organisasi dan loyalitas untuk tetap menjadi anggota organisasi. Oleh karena itu, komitmen organisasi akan menimbulkan rasa ikut memiliki bagi pekerja terhadap organisasi. Jika pekerja merasa jiwa terikan dengan nilainilai organisasional yang ada maka ia akan merasa senang dalam bekerja, sehingga kinerjanya dapat meningkat.

Keberhasilan dan kinerja seseorang dalam suatu bidang pekerjaan sangat ditentukan oleh profesionalisme terhadap bidang yang ditekuninya. Profesionalisme sendiri harus ditunjang dengan komitmen serta indepensi untuk mencapai tingkatan 
yang tertinggi. Komitmen merupakan suatu konsistensi dari wujud keterikatan seseorang terhadap suatu hal, seperti : Karir, keluarga, lingkungan pergaulan sosial dan sebagainya. Adanya suatu komitmen dapat menjadi suatu dorongan bagi seseorang untuk bekerja lebih baik atau malah sebaliknya menyebabkan seseorang meninggalkan pekerjaanya, akibat suatu tuntutan komitmen lainnya. Komitmen yang tepat akan memberikan motivasi yang tinggi dan memberikan dampak yang positif terhadap kinerja suatu pekerjaan. Berdasarkan hal tersebut, maka hipotesis pertama yang diajukan dalam penelitian ini adalah sebagai berikut:

$\mathrm{H}_{2}$ : Komitmen Organisasi berpengaruh positif pada kinerja perusahaan.

Motivasi kerja berpengaruh positif terhadap kinerja perusahaan. Oleh karena itu dapat dipastikan bahwa peningkatan motivasi kerja akan berdampak positif terhadap kenaikan tingkat kinerja perusahaan. Sehingga dapat dipastikan bahwa karyawan yang termotivasi adalah karyawan yang puas dengan pekerjaan yang di jalankan.Sebagai dorongan untuk bekerja itu sendiri, motivasi kerja berpengaruh langsung terhadap semangat kerja seseorang.

Orang yang memiliki motivasi untuk bekerja akan lebih berkomitmen didalam pekerjaan. Secara langsung, semangat kerja tersebut akan meningkatkan kinerja seseorang. Semakin besar kinerja seorang pekerja, maka produktivitas mereka akan meningkat. Hal ini tentu berpengaruh secara langsung terhadap kemampuan seseorang, terutama dalam memenuhi kebutuhan dan keinginan mereka untuk mencapai tujuan organisasi atau perusahaan.

$\mathrm{H}_{3}$ : Motivasi Kerja berpengaruh positif pada kinerja perusahaan.

\section{METODE PENELITIAN}

Lokasi penelitian dilakukan di PT Sejahtera Indobali Trada. PT Sejahtera Indobali Trada berdiri sejak tahun 2003 yang awal mulanya bergerak di bidang sales kemudian berkembang dan membangun gedung baru sejak tahun 2015 menambah bidang pelayanan yang ditawarkan ke konsumen menjadi 3 bidang, yakni sales, service dan sparepart. Objek dalam penelitian ini adalah karyawan yang bekerja di PT. Sejahtera Indobali Trada.

Populasi dalam penelitian ini adalah seluruh karyawan yang bekerja pada PT. Sejahtera Indobali Trada di seluruh Cabang di Bali yang berjumlah 250 orang. Metode penentuan sampel yang digunakan adalah metode nonprobabilitas (nonprobability sampling methods) dengan teknik purposive sampling dan perhitungan menggunakan rumus Slovin maka diperoleh sebanyak 46 responden.

Teknik analisis data yang digunakan dalam penelitian ini adalah teknik analisis kuantitatif. Analisis ini meliputi analisis regresi linear berganda. Analisis tersebut dapat dihitung dengan menggunakan alat bantu komputer melalui software SPSS.

Uji hipotesis melalui analisis regresi linear berganda, adalah untuk mencari pengaruh Gaya Kepemimpinan $\left(X_{1}\right)$, Komitmen Organisasi $\left(X_{2}\right)$, dan Motivasi kerja $\left(\mathrm{X}_{3}\right)$ terhadap Kinerja Perusahaan $(\mathrm{Y})$. Model regresi linear ganda yang digunakan adalah dengan menggunakan persamaan sebagai berikut:

Keterangan :

$$
Y=\alpha+\beta_{1} X_{1}+\beta_{2} X_{2}+\beta_{3} X_{3}+e
$$

$\mathrm{Y}=$ kinerja perusahaan 
$\alpha=$ konstan

$\mathrm{X}_{1}=$ gaya kepemimpinan

$\mathrm{X}_{2}=$ komitmen organisasi

$\mathrm{X}_{3}=$ motivasi kerja

$\beta_{1}=$ koefisien regresi gaya kepemimpinan

$\beta_{2}=$ koefisien regresi komitmen organisasi

$\beta_{3}=$ koefisien regresi motivasi kerja

$\mathrm{e}=$ komponen pengganggu

\section{HASIL DAN PEMBAHASAN}

Uji normalitas bertujuan untuk menguji apakah dalam model regresi, variabel residual mempunyai distribusi data normal atau mendekati normal. Untuk menguji apakah data yang digunakan normal atau tidak dapat dilakukan dengan menggunakan uji Kolmogorov-Smirnov dengan melihat nilai Asymp. Sig. (2-tailed). Berdasarkan hasil analisis, diperoleh hasil seluruh variabel di atas 0,05 yang artinya data berdistribusi normal.

Tabel 2. Hasil Uji Normalitas

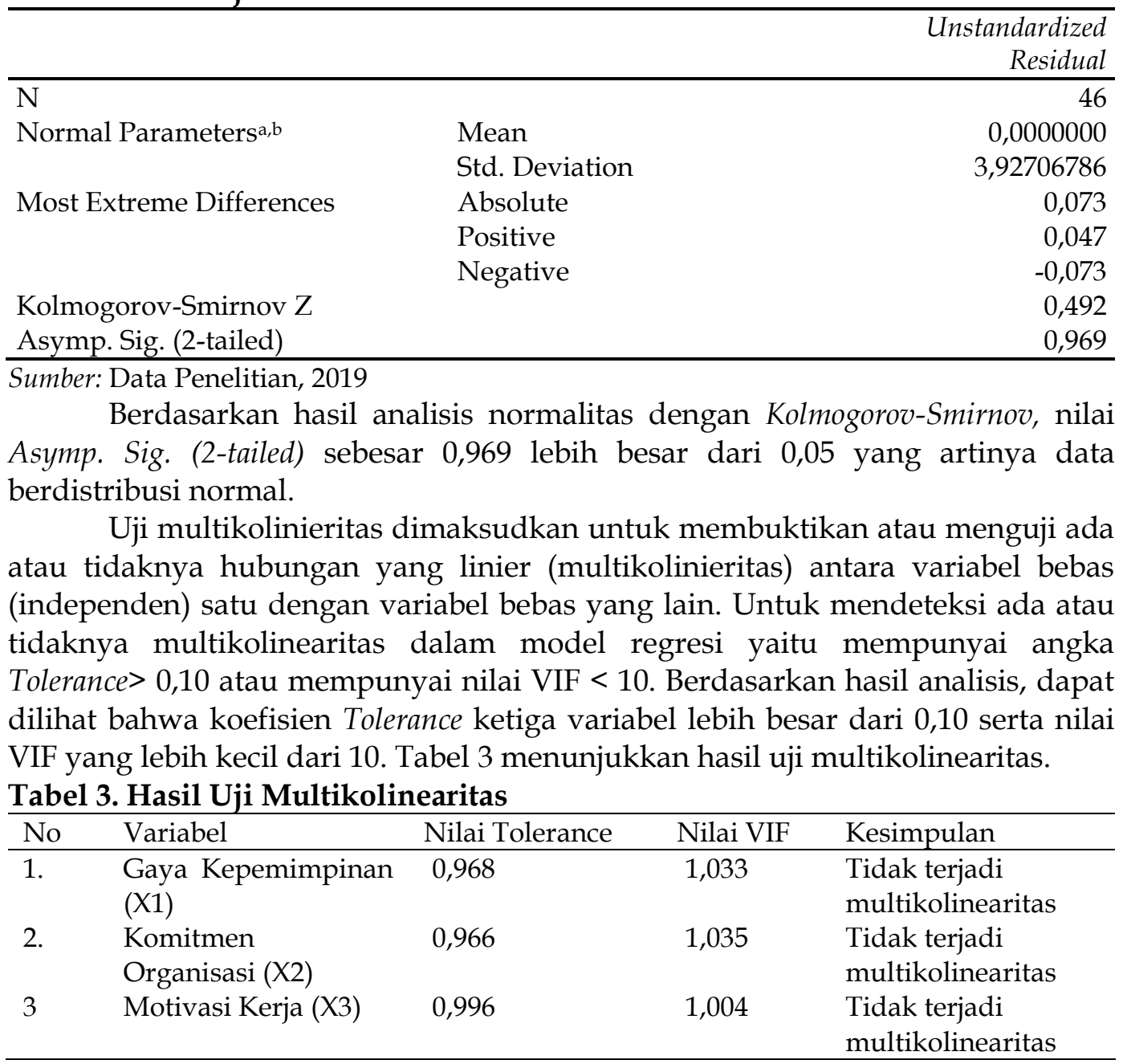

Sumber: Data Penelitian, 2019 
Hasil uji multikolinearitas pada Tabel 3 menunjukkan bahwa nilai tolerance variabel bebas berada di atas 0,1 dan nilai VIF berada di bawah 10. Jadi dapat disimpulkan bahwa model tidak terdapat gejala multikolinearitas.

Uji heterokedastisitas dilakukan untuk mengetahui bahwa pada model regresi terjadi ketidaksamaan varian. Untuk mengetahui ada atau tidaknya heteroskedastisitas yaitu dengan melakukan Uji Glejser dengan meregresi nilai absolut terhadap variabel independen, dengan ketentuan jika nilai signifikan diatas 0,05 maka memiliki arti tidak terjadi heteroskedastisitasdengan syarat nilai signifikansi berada di atas 0,05 yang berarti tidak terdapat heteroskedastisitas. Hasil uji ini dapat dilihat pada Tabel 4.

Tabel 4. Hasil Uji Heteroskedastisitas

\begin{tabular}{llcl}
\hline No & Variabel & Sig. & Keterangan \\
\hline 1. & Gaya Kepemimpinan (X1) & 0,699 & Bebas heteroskedastisitas. \\
2 & Komitmen Organisasi (X2) & 0,838 & Bebas heteroskedastisitas \\
3 & Motivasi Kerja (X3) & 0,972 & Bebas heteroskedastisitas. \\
\hline
\end{tabular}

Sumber: Data Penelitian, 2019

Pada tabel 4 memperlihatkan tingkat signifikansi tiap variabel bebas di atas 0,05 sehingga dapat disimpulkan model regresi terbebas dari heteroskedastisitas.

Tabel 5. Analisis Regresi Linier Berganda

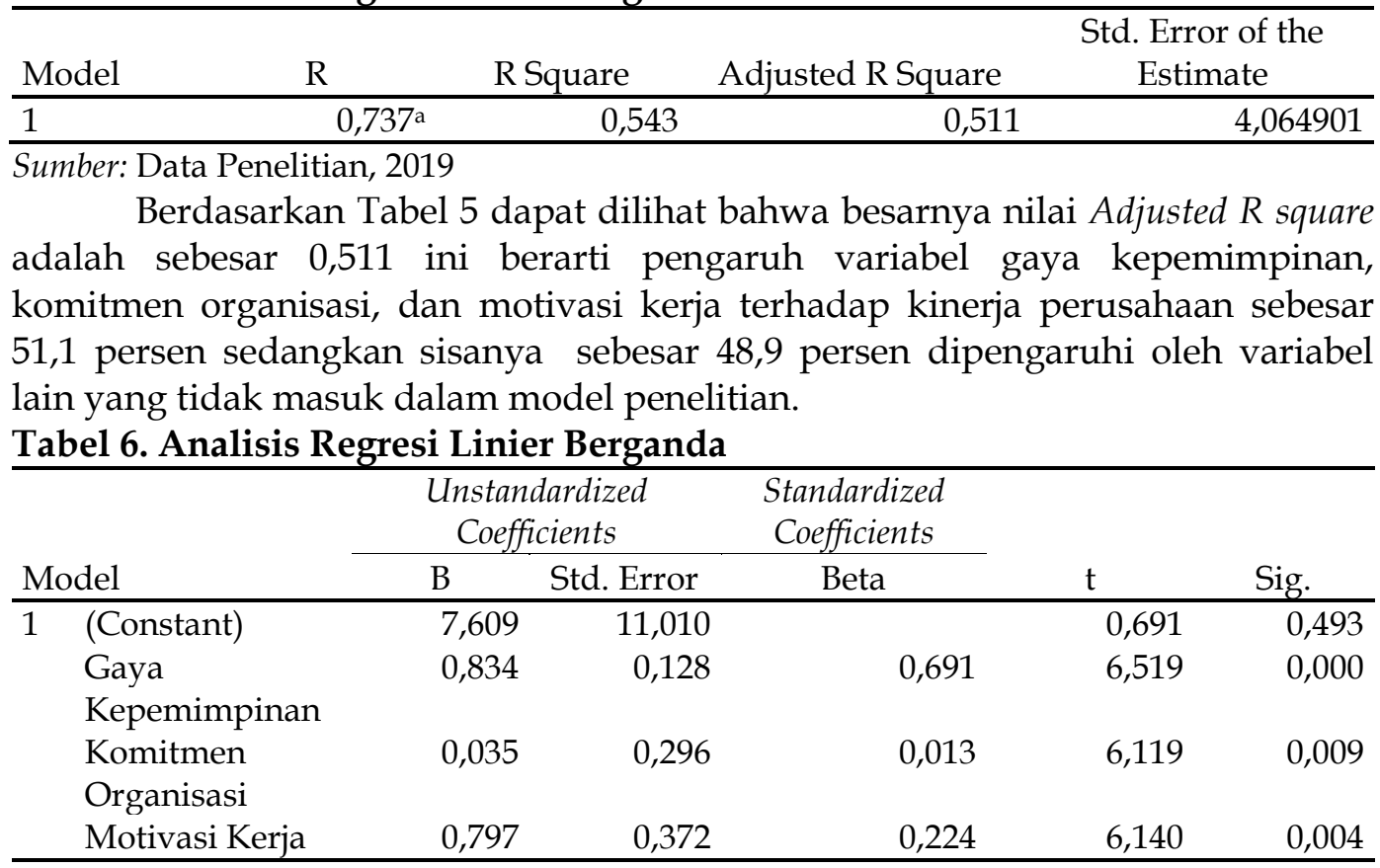

Sumber: Data Penelitian, 2019

Pada tabel 6 dapat dilihat nilai koefisien regresi dari variabel bebas gaya kepemimpinan, komitmen organisasi, dan motivasi kerja dan konstanta variabel terikat (kinerja perusahaan), maka diperoleh persamaan regresi linier berganda sebagai berikut :

$$
Y=7,609+0,834\left(X_{1}\right)+0,035\left(X_{2}\right)+0,797\left(X_{3}\right)+e
$$

Berdasarkan persamaan tersebut, maka variabel gaya kepemimpinan, komitmen organisasi, dan motivasi kerja berpengaruh positif terhadap kinerja perusahaan pada karyawan PT. Sejahtera Indobali Trada. Diketahui konstanta 
besarnya 7,609 mengandung arti jika variabel gaya kepemimpinan $\left(X_{1}\right)$, komitmen organisasi $\left(X_{2}\right)$,dan motivasi kerja $\left(X_{3}\right)$ tidak ada berubah, maka kinerja perusahaan $(Y)$ bernilai sama dengan nilai konstanta yaitu 7,609.

Tabel 7. Hasil Uji Hipotesis (Uji F)

\begin{tabular}{|c|c|c|c|c|c|c|}
\hline \multicolumn{2}{|c|}{ Model } & Sum of Squares & $\overline{\text { Df }}$ & Mean Square & $\mathrm{F}$ & Sig. \\
\hline \multirow[t]{3}{*}{1} & Regression & 825,422 & 3 & 275,141 & 16,652 & $0,000^{a}$ \\
\hline & Residual & 693,984 & 42 & 16,523 & & \\
\hline & Total & 1519,405 & 45 & & & \\
\hline
\end{tabular}

Sumber: Data Penelitian, 2019

Oleh karena $\mathrm{F}$ hitung sebesar 16,652 dengan nilai signifikan 0,000 $<0,05$ maka hal tersebut menunjukkan bahwa Ho ditolak. Ini berarti variabel Gaya Kepemimpinan, Komitmen Organisasi dan Motivasi Kerja berpengaruh secara simultan terhadap variabel Kinerja Perusahaan PT. Sejahtera Indobali Trada dan hal ini menunjukkan bahwa persamaan regresi layak digunakan sebagai prediksi kinerja.

Uji t dilakukan untuk melihat pengaruh variabel Gaya Kepemimpinan, Komitmen Organisasi dan Motivasi Kerjaterhadap variabel Kinerja Perusahaan secara parsial. Hasil Uji t dapat dilihat pada Tabel 8.

Tabel 8. Hasil Uji Hipotesis (Uji t)

\begin{tabular}{llcc}
\hline No & \multicolumn{1}{c}{ Variabel } & thitung $_{\text {ignifikansi }}$ & Signa \\
\hline 1 & Gaya Kepemimpinan & 6,519 & 0,000 \\
2 & Komitmen Organisasi & 6,119 & 0,009 \\
3 & Motivasi Kerja & 6,140 & 0,004 \\
\hline
\end{tabular}

Sumber: Data Penelitian, 2019

Oleh karena thitung pada variabel gaya kepemimpinan sebesar 6,519 dengan nilai signifikan $0,000<\mathrm{a}(0,05)$ maka $\mathrm{H}_{0}$ dalam penelitian ini adalah ditolak. Hal ini berarti variabel Gaya Kepemimpinan berpengaruh positif signifikan secara parsial terhadap variabel kinerja perusahaan pada karyawan PT. Sejahtera Indobali Trada.

Oleh karena $\mathrm{t}$ hitung pada variabel komitmen organisasi sebesar 6,119dengan nilai sig 0,009<a $(0,05)$ maka $\mathrm{H}_{0}$ pada penelitian ini adalah ditolak. Hal ini berarti variabel Komitmen Organisasi berpengaruh positif signifikan secara parsial terhadap variabel Kinerja Perusahaan pada karyawan PT. Sejahtera Indobali Trada.

Oleh karena thitung pada variabel motivasi kerja sebesar 6,140 dengan nilai sig $0,004<a(0,05)$ maka $\mathrm{H}_{0}$ da penelitian ini adalah ditolak. Hal ini berarti variabel Motivasi Kerja berpengaruh positif signifikan secara parsial terhadap variabel Kinerja Perusahaan pada karyawan PT. Sejahtera Indobali Trada.

Hasil pengujian hipotesis menunjukkan bahwa terdapat pengaruh yang positif dan signifikan variabel Gaya Kepemimpinanterhadap Kinerja Perusahaan pada karyawan PT. Sejahtera Indobali Trada, artinya peningkatan pada Gaya Kepemimpinan akan diikuti oleh peningkatan pada Kinerja Perusahaan. Penelitian lain yang mendukung hasil penelitian ini adalah hasil penelitian dari Tampi (2014) yang dalam penelitiannya yang berjudul "Pengaruh Gaya Kepemimpinan Dan Motivasi Terhadap Kinerja KaryawanPada PT. Bank Negara Indonesia,Tbk. (Regional Sales Manado)", memperoleh hasil bahwa gaya kepemimpinan berpengaruh positif signifikan terhadap kinerja karyawan. 
Pengaruh positif tersebut menunjukkan adanya pengaruh yang searah antara gaya kepemimpinan dengan kinerja perusahaan, atau dengan kata lain dengan gaya kepemimpinan baik maka kinerja perusahaan tinggi. Hal ini juga didukung oleh hasil penelitian Kharis (2015), yang memeproleh hasil bahwa secara langsung gaya kepemimpinan berpengaruh secara positif signifikan terhadap kinerja perusahaan. Sedangkan pengaruh yang signifikan ini menunjukkan bahwa gaya kepemimpinan berpengaruh terhadap kinerja perusahaan.

Kepemimpinan berpengaruh positif kuat terhadap kinerja, juga berpengaruh signifikan terhadap learning organisasi. Temuan ini memberikan indikasi bahwa gaya kepemimpinan seorang pemimpin sangat berpengaruh terhadap kinerja bawahannya, di samping itu untuk mendapatkan kinerja yang baik diperlukan juga adanya pemberian pembelajaran terhadap bawahannya.

Hasil pengujian hipotesis menunjukkan bahwa terdapat pengaruh yang positif dan signifikan variabel Komitmen Organisasi terhadap Kinerja Perusahaan pada karyawan PT. Sejahtera Indobali Trada, artinya peningkatan pada Komitmen Organisasi maka akan diikuti dengan peningkatan pada Kinerja Perusahaan. Hasil penelitian Sapitri (2016) dan Fauzan (2015) memperoleh hasil penelitian yang meunjukkan bahwa komitmen organisasi berpengaruh signifikan positif terhadap kinerja karyawan. Komitmen organisasional dibangun atas dasar kepercayaan pekerja atas nilai-nilai organisasi, kerelaan pekerja membantu mewujudkan organisasi dan loyalitas untuk tetap menjadi anggota organisasi. Oleh karena itu, komitmen organisasi akan menimbulkan rasa ikut memiliki bagi pekerja terhadap organisasi. Jika pekerja merasa jiwa terikan dengan nilai-nilai organisasional yang ada maka ia akan merasa senang dalam bekerja, sehingga kinerjanya dapat meningkat.

Keberhasilan dan kinerja seseorang dalam suatu bidang pekerjaan sangat ditentukan oleh profesionalisme terhadap bidang yang ditekuninya. Profesionalisme sendiri harus ditunjang dengan komitmen serta indepensi untuk mencapai tingkatan yang tertinggi. Komitmen merupakan suatu konsistensi dari wujud keterikatan seseorang terhadap suatu hal, seperti : Karir, keluarga, lingkungan pergaulan sosial dan sebagainya. Adanya suatu komitmen dapat menjadi suatu dorongan bagi seseorang untuk bekerja lebih baik atau malah sebaliknya menyebabkan seseorang meninggalkan pekerjaanya, akibat suatu tuntutan komitmen lainnya. Komitmen yang tepat akan memberikan motivasi yang tinggi dan memberikan dampak yang positif terhadap kinerja suatu pekerjaan.

Hasil pengujian hipotesis menunjukkan bahwa terdapat pengaruh yang positif dan signifikan variabel Motivasi Kerja terhadap Kinerja Perusahaan pada karyawan PT. Sejahtera Indobali Trada, artinya peningkatan pada Motivasi Kerja maka akan diikuti dengan peningkatan pada Kinerja Perusahaan. Hasil penelitian ini sejalan dengan penelitian yang dilakukan oleh Larasati (2014) memperoleh hasil penelitian yang menunjukkan bahwa motivasi kerja berpengaruh terhadap kinerja perusahaan, sedangkan hasil penelitian dari Lumantow, dkk (2018), memperoleh hasil bahwa motivasi tidak ada hubungan atau tidak berpengaruh terhadap kinerja perusahaan.

Menurut Mangkunegara (2005:101) mengemukakan bahwa terdapat 2 (dua) teknik memotivasi kerja pegawai yaitu: (1) Teknik pemenuhan kebutuhan pegawai, 
artinya bahwa pemenuhan kebutuhan pegawai meru- pakan fundamen yang mendasari perilaku kerja. (2) Teknik komunikasi persuasif, adalah merupakan salah satu teknik memotivasi kerja pegawai yang dilakukan dengan cara mempengaruhi pegawai secara ekstra logis. Teknik ini dirumuskan dengan istilah "AIDDAS" yaitu Attention (perhatian), Interest (minat), Desire (hasrat), Decision (keputusan), Action (aksi atau tindakan), dan Satisfaction (kepuasan). Dalam motivasi terdapat beberapa teori yang dikemukakan oleh salah seorang ilmuan yang dipandang sebagai pelopor teori motivasi adalah Maslow yang memisahkan lima kebutuhan ke dalam urutan-urutan yang lebih tinggi dan lebih rendah. Urutan tingkat kebutuhankebutuhan tersebut meliputi kebutuhan fisiologi, rasa aman, socsial, penghargaan dan aktuaklisasi diri.

Orang yang memiliki motivasi untuk bekerja akan lebih berkomitmen didalam pekerjaan. Secara langsung, semangat kerja tersebut akan meningkatkan kinerja seseorang. Semakin besar kinerja seorang pekerja, maka produktivitas mereka akan meningkat. Hal ini tentu berpengaruh secara langsung terhadap kemampuan seseorang, terutama dalam memenuhi kebutuhan dan keinginan mereka untuk mencapai tujuan organisasi atau perusahaan. Motivasi kerja berpengaruh positif terhadap kinerja perusahaan. Oleh karena itu dapat dipastikan bahwa peningkatan motivasi kerja akan berdampak positif terhadap kenaikan tingkat kinerja perusahaan. Sehingga dapat dipastikan bahwa karyawan yang termotivasi adalah karyawan yang puas dengan pekerjaan yang di jalankan.Sebagai dorongan untuk bekerja itu sendiri, motivasi kerja berpengaruh langsung terhadap semangat kerja seseorang.

Respon karyawan terhadap berbagai aspek gaya kepemimpinan, komitmen organisasi, dan motivasi kerja menunjukkan sebagian besar karyawan menunjukkan kinerja yang cukup maksimal, yang ditunjukkan dengan hasil penjualan PT. Sejahtera Indobali Trada tahun 2018. Hal ini tentunya tidak terlepas dari faktor gaya kepemimpinan, komitmen organisasi, serta adanya motivasi kerja yang cukup memadai dari karyawan.

Kondisi tersebut tentunya harus terus ditingkatkan dan lebih mendapatkan perhatian bagi pihak manajemen dengan memperhatikan aspek yang dinyatakan oleh karyawan dengan memberikan tanggung jawab pada karyawan untuk hasil kerja yang dilakukannya sehingga akan memotivasi karyawan untuk lebih giat bekerja, memberikan karyawan kesempatan untuk memberi usulan didalam pemecahan masalah yang ada didalam organisasi, memberikan penghargaan kepada karyawan berprestasi dan memberikan sanksi pada karyawan yang lalai sehingga dapat meningkatkan kinerja karyawan dan kinerja perusahaan pada PT. Sejahtera Indobali Trada.

Hasil penelitian ini tidak dapat membuktikan teori yang digunakan dalam penelitian ini yaitu teori teoripertukaran sosial (Social Exchange) dan teori motivasi. Penelitian ini juga dapat menambah referensi, informasi, wawasan, dan memberikan pemahaman yang lebih luas berkaitan dengan kinerja perusahaan, gaya kepemimpinan, komitmen organisasi dan motivasi kerja.

Hasil penelitian ini diharapkan akan memberikan kontribusi positif bagi pihak-pihak yang berkepentingan, utamanya pihak manajemenPT. Sejahtera Indobali Tradamengenai pentingnya gaya kepemimpinan, komitmen organisasi, dan motivasi kerja karyawan, sehingga kinerja perusahaan pada PT. Sejahtera 
Indobali Trada dapat mengalami peningkatan. Perusahaan hendaknya memperhatikan bagaimana cara memimpin agar kinerja perusahaan tidak rendah dengan cara memberikan motivasi kerja dan meningkatkan komitmen organisasi dari karyawan sehingga mampu tercapainya tujuan perusahaan.

Penelitian ini memiliki keterbatasan yaitu jumlah responden hanya 46 karyawan Supervisor dan hanya dari lingkungan PT. Sejahtera Indobali Trada, sehingga hasil penelitian ini hanya dapat diterapkan dilingkungan PT. Sejahtera Indobali Tradadan tidak dapat digeneralisir pada lingkungan perusahan lainnya.

\section{SIMPULAN}

Terdapat pengaruh yang positif dan signifikan variabel Gaya Kepemimpinan terhadap Kinerja Perusahaan pada karyawan PT. Sejahtera Indobali Trada. Semakin sesuai dan bagus gaya kepemimpinan yang diterapkan perusahaan, semakin tinggiKinerja Perusahaan pada karyawan PT. Sejahtera Indobali Trada.

Terdapat pengaruh yang positif dan signifikan variabel Komitmen Organisasi terhadap Kinerja Perusahaan pada karyawan PT. Sejahtera Indobali Trada. Semakin tinggi komitmen organisasi yang dimiliki karyawan, semakin tinggiKinerja Perusahaan pada karyawan PT. Sejahtera Indobali Trada.

Terdapat pengaruh yang positif dan signifikan variabel Motivasi Kerja terhadap Kinerja Perusahaan pada karyawan PT. Sejahtera Indobali Trada. Semakin tinggiMotivasi Kerja yang dimiliki karyawan, semakin tinggipula Kinerja Perusahaan pada karyawan PT. Sejahtera Indobali Trada.

Saran bagi pihak pengelolaatau manjemen PT. Sejahtera Indobali Trada berdasarkan hasil dari penelitian ini yang memeproleh hasil bahwa gaya kepemimpinan, komitmen organisasi, dan motivasi kerja berpengaruh positif terhadap kinerja perusahaan, sehingga diharapkan untuk dapat menyesuaikan gaya kepemimpinannya, meningkatkan komitmen organisasi dan motivasi kerja dari karyawan agar dapat meningkatkan kinerja dari perusahaan dengan memberikan tanggung jawab pada karyawan untuk hasil kerja yang dilakukannya, memberikan dorongan berupa bonus maupun kenaikan gaji bagi karyawan yang berprestasi, memberikan karyawan kesempatan untuk memberi usulan di dalam pemecahan masalah yang ada didalam organisasi, dan memberikan karyawan kebebasan memutuskan bagaimana melakukan pekerjaan terkait tugas pokok. Selain itu, pihak manajemen juga diharapkan dapat mengelola tekanan kerja agar dapat meningkatkan komitmen organisasional karyawan dengan memberikan karyawan pekerjaan yang tidak melebihi daya tahan tubuh, jangan memberikan pekerjaan melebihi usaha karyawan pada umumnya di dalam melakukan pekerjaan.

Bagi peneliti lain yang berminat untuk mendalami bidang akuntansi khususnya yang berkaitan dengan sumber daya manusia disarankan untuk mengembangkan penelitian ini dengan mengembangkan metode yang berbeda misalnya kualitatif deskriftif pada subjek yang berbeda. Hal ini berguna untuk menguji keberlakuan temuan faktor-faktor yang mempengaruhi kinerja perusahaan, agar hasilnya lebih maksimal. 


\section{REFERENSI}

Basuki, R. (2016). Pengaruh Gaya Kepemimpinan dan Komitmen Organisasi Terhadap Kinerja Pegawai Negeri Sipil Fakultas Teknik Universitas Sebelas Maret Surakarta dengan Motivasi sebagai Pemediasi. Publikasi Ilmiah Program Magister Manajemen Pascasarjana Universitas Muhammadiyah Surakarta.

Fauzan, A. H. (2015). Pengaruh Komitmen Organisasi terhadap Kinerja Karyawan PT Bank Mandiri Tbk. Area Cirebon (Yos Sudarso). Repository.upi.edu, 3(3), 34-42.

Handoko, T. H. (2003). Manajemen (2nd ed.). Yogyakarta: BPFE.

Hendrianto, J. (2015). Pengaruh Motivasi dan Kompensasi terhadap Kinerja Karyawan pada PT Bangun Karya. Agora, 3(2), 128-133.

Kharis, I. (2015). Pengaruh Gaya Kepemimpinan Transformasional Terhadap Kinerja Karyawan Dengan Motivasi Kerja Sebagai Variabel Intervening (Studi Pada Karyawan Bank Jatim Cabang Malang). Jurnal Administrasi Bisnis, 20(1).

Larasati, S. (2014). Pengaruh Motivasi Kerja terhadap Kinerja Karyawan Wilayah Telkom Jabar Barat Utara (Witel Bekasi). Jurnal Manajemen Dan Organisasi, $5(3)$.

Lumantow, R. ., Tewal, B., \& Lengkong, V. P. . (2018). Pengaruh Motivasi Dan Kepuasan Kerja Terhadap Kinerja Karyawan Dimoderasi Oleh Masa Kerja Pada PT. Deho Canning Company Bitung. Jurnal EMBA, 3(1), 717-725.

Mangkunegara, A.A Anwar Prabu. 2005. Manajemen Sumber Daya Manusia Perusahaan. Bandung: PT. Remaja Rosdakarya.

Parlinda, V., \& Wahyuddin, M. (2004). Pengaruh Kepemimpinan, Motivasi, Pelatihan, Dan Lingkungan Kerja Terhadap Kinerja Karyawan Pada Perusahaan Daerah Air Minum Kota Surakarta. UDiNus Repository.

Risqi, R. O., Ushada, M., \& Supartono, W. (2015). Analisis Pengaruh Kepuasan Kerja Terhadap Kinerja Karyawan Dengan Pendekatan Kansei Engineering Perusahaan XYZ. Agritech, 35(1), 78-87.

Sapitri, R. (2016). Pengaruh Komitmen Organisasi Terhadap Kinerja Karyawan Perusahaan Listrik Negara Area Pekanbaru. JOM Fisip, 3(2).

Susantoso, J. (2013). Pengaruh Gaya Kepemimpinan, Lingkungan Kerja Dan Budaya Organisasi Terhadap Kinerja Pegawai Dengan Mediasi Kepuasan Kerja Di Dinas Pendapatan, Pengelolaan Keuangan Dan Aset Daerah Kabupaten Pati. Universitas Muria Kudus.

Suwati, Y. (2013). Pengaruh Kompensasi dan Motivasi Kerja Terhadap Kinerja Karyawan pada PT. Tunas Hijau Samarinda. E-Jurnal Ilmu Administrasi Bisnis, 1(1), 41-55.

Tampi, B. J. (2014). Pengaruh Gaya Kepemimpinan Dan Motivasi Terhadap Kinerja Karyawan Pada PT. Bank Negara Indonesia,Tbk (Regional Sales Manado). Journal Acta Diurna, 3(4).

Yukl, G. (2013). Leadership In Organizations (8th ed.). Albany: Pearson. 